\title{
THE EFFECT OF DIFFERENT KIND OF POLYETHYLENE FILM USED AS A LOW TUNNEL COVER ON CELERY YIELD AND STALK QUALITY
}

\author{
Piotr SIWEK ${ }^{1}$, Renata WOJCIECHOWSKA ${ }^{2}$, Andrzej LIBIK ${ }^{1}$, Andrzej KALISZ ${ }^{1}$ \\ ${ }^{1}$ Department of Vegetable Crops, Agricultural University in Kraków \\ 2 Department of Plant Physiology, Agricultural University in Kraków \\ 29 Listopada 54, 31-425 Kraków, Poland
}

Received: March 30, 2009; Accepted: June 4, 2009

\begin{abstract}
Summary
Earlier experiments showed that celery could be grown under different plastic covers for spring and autumn harvest. The most significant for yield quantity and quality were light conditions. In conducted studies (2005-2007) the effect of three different covers for low tunnels: transparent, white and black film (made of original and recycled polyethylene) on the growth, yield and some quality factors of celery Tango stalks was estimated. Only small differences in the length of celery stalks grown under different films were observed. In the third year of experiment stalks grown under black film were around $1 \mathrm{~cm}$ longer than all the others. Mean values of the yield indicate that transparent film used as a cover and the control treatment increased slightly the obtained yield but the differences did not exceed several percent. Plants grown in more favourable light conditions accumulated more dry matter as well as more soluble sugars in celery stalks. No such differences were observed under original and recycled films.
\end{abstract}

key words: recycled and original film, celery, yield, soluble sugars

\section{INTRODUCTION}

Previous studies demonstrated that celery can be grown under direct covers of perforated film, in tunnels for early harvest and under non-woven fabrics for autumn harvest (Dyduch 1994, Siwek 2002). Regardless the kind of the cover, photosyntethically active radiation (PAR) is the most significant factor for the microclimate conditions, both in respect to the quantity and quality of light. In earlier studies on permeability for PAR $(400-700 \mathrm{~nm})$ and NIR (near infrared) $(700-1100 \mathrm{~nm})$ through polyethylene films and non-woven polypropylene materials used to cover low tunnels Siwek and Libik (1999) demonstrated that films in natural, blue, green and red colour transmitted $89-92 \%$

Grant sponsor: Ministry of Science and High Education of Poland (No 2P06R07426)

Corresponding author:

e-mail: psiwek@ogr.ar.krakow.pl

(C) Copyright by RIVC 
of PAR and $86-91 \%$ of NIR. When these results were compared to non-woven materials in same colours, it was shown that transmission was on same level only in case of natural colour non-woven (87-88\%). Transmission through nonwoven of other colours was $49-51 \%$ and $28-42 \%$ of PAR and NIR, respectively. Thermal conditions under covers depend on lighting conditions, but these are not always favourable for plants. In other studies it was demonstrated that in tunnels covered with thin transparent film on sunny spring days air temperature may rapidly increase, leading to plant burn (Libik \& Siwek 1994, Kalisz \& Cebula 1995). Attempts to limit the intensity of radiation in late spring and summer using shadings led to temperature fall which weakened the plant growth and resulted in lower yield of sweet pepper and cucumber (Siwek \& Libik 1999, Siwek \& Ciura 1999). In case of celery shading with various materials gave positive results in earlier experiments. Covering plants with non-woven materials in spring for 25 days from planting increased the marketable yield by 1319\% comparing to control (Jenni \& Stewart 1992). Soil mulching and covering low-structure tunnels with transparent film significantly decreased bolting and led to obtain a better yield (Jenni et al. 2006). Covering celery plants with nonwoven fabric one month before harvest resulted in the increase of the marketable yield by over 50\% during autumn cultivation (Siwek 2002). In effect of covering, obtained stalks were of very good quality, however the dry matter content was lower than average. (Pressman 1997).

The aim of this study was to investigate the effect of microclimatic conditions in low tunnels with different solar radiation permeability on the growth, yield and selected quality features of stalks in the celery cultivation for early harvest.

\section{MATERIAL AND METHODS}

The experiments were carried out in 2005-2007 in the Experimental Station at Mydlniki by Krakow. It concerned medium-early celery cultivar of Tango intensively green leaves. Celery seeds were sown in the greenhouse on 4 February 2005, 6 February 2006 and 5 February 2007. Transplants were planted in the field at $30 \times 25 \mathrm{~cm}$ spacing on 20 April in the first year, on 19 April in the second year and 17 April in the third year of conducted experiment. The experimental plots, each of $3 \mathrm{~m}^{2}$ (40 plants), were established in a randomised block design with four replicates. The experiment concerned covering tunnels with low density polyethylene films (PE) which differed in respect to the material they were made of and colour: 1) without cover (control), 2) transparent from original PE; 3) transparent from recycled PE; 4) white from original PE; 5) white from recycled PE; 6) black from original PE; 7) black from recycled PE. Original films were made of Basell Orlen Polyolefins polyethylene and recycled films of high quality polyethylene originating from waste products. White (Schulman 8160) and black (Polybatch black 1850) dyes were used as colouring agents. Tunnels $10 \mathrm{~m}$ long, $1.5 \mathrm{~m}$ wide and $0.8 \mathrm{~m}$ high were covered with above mentioned films and stayed covered till 30 May 2005 in the first year of trial, 
until 31 May 2006 in the second year and 2 June 2007 in the third year of conducted experiments. When air temperature was above $20^{\circ} \mathrm{C}$ tunnels were kept open. Celery was harvested only once on 6th, 13th, and 3rd July in consecutive years.

In all years of the experiment manure $\left(35,000 \mathrm{~kg} \cdot \mathrm{ha}^{-1}\right)$, triple superphosphate $\left(150 \mathrm{~kg} \mathrm{P}_{2} \mathrm{O}_{5} \cdot \mathrm{ha}^{-1}\right)$ and potash salt $\left(200 \mathrm{~kg} \mathrm{~K}_{2} \mathrm{O} \cdot \mathrm{ha}^{-1}\right)$ were applied in autumn. In spring, before planting, field was fertilized with nitrogen (nitrochalk) in following doses: $50 \mathrm{~kg} \mathrm{~N} \cdot \mathrm{ha}^{-1}$ in $2005,75 \mathrm{~kg} \mathrm{~N} \cdot \mathrm{ha}^{-1}$ in 2006 and $50 \mathrm{~kg}$ $\mathrm{N} \cdot \mathrm{ha}^{-1}$ in 2007 . At the growth stage celery was fertilized with ammonium nitrate $\left(25 \mathrm{~kg} \mathrm{~N} \cdot \mathrm{ha}^{-2}\right)$, and $0.1 \% \mathrm{Ca}\left(\mathrm{NO}_{3}\right)_{2}\left(20 \mathrm{dm}^{3} \cdot \mathrm{m}^{-2}\right)$.

Used films were analyzed in respect to spectral transmission, reflection and absorption of radiation within the range of 400-1100 nm, using LI-1800-12S (LI-COR, USA) integration sphere with standard light source, in accordance with the world standard procedure (Siwek et al. 2007). PAR transmission through the films was recorded with PAR Smart Sensor HOBO (Onset Comp. Corp.) on samples of all film mounted on a special tunnel-shape construction. Air temperature was recorded using HOBO Pro (Onset Comp.Corp.) during the time when celery was covered.

In order to determine the dry matter content samples of plant material were dried at $95^{\circ} \mathrm{C}$. Soluble sugar content was determined by the photometric method with antrone reagent (Yemm \& Wills 1954). ANOVA was used for statistical analysis of obtained results and the means were compared using NewmannKeuls test at the $\mathrm{P}=0.05$.

\section{RESULTS}

Measurements conducted on film samples demonstrated that particular colours had various effect on light conditions. Results presented in Table 1 indicate that the sum of PAR transmitted through films was: $72.2 \%$ for transparent, $48.7 \%$ for white and $23.2 \%$ for black film. Mean values of PAR under particular films during the day confirmed the results obtained for control conditions (Siwek et al. 2007).

Temperature under films was higher than the soil temperature and the differences were related to light permeability (Table 2). In all years of the experiment the highest daily temperature was noted under transparent film $\left(3.7^{\circ} \mathrm{C}\right.$ higher when compared to control). The minimal noted temperature was higher by $1.1^{\circ} \mathrm{C}$ and the maximal temperature was higher by $6.5^{\circ} \mathrm{C}$ comparing to control. Under less permeable white film differences comparing to control were: $1.2,0.8$ and $3.0^{\circ} \mathrm{C}$, respectively. Black film modified temperature to the least degree. Under this film the mean daily temperature was higher only by $0.8^{\circ} \mathrm{C}$, while the minimal and maximal temperatures by 0.1 and $1.9^{\circ} \mathrm{C}$, respectively. In 2005 values of PAR and temperature under covers were lowest comparing to other years. No differences in the temperatures were observed between original and recycled films. 
Table 1. Total daily PAR $\left(\mu \mathrm{mol} \cdot \mathrm{m}^{-2} \cdot \mathrm{s}^{-1}\right)$ under film of different colours made from original or recycled material

\begin{tabular}{lccccc}
\hline & \multicolumn{5}{c}{ Total daily PAR } \\
\cline { 2 - 6 } \multicolumn{1}{c}{ Treatments } & 20 April - & 19 April - & 20 April - & Mean & Mean \\
& 4 May & 23 May & 2 June & 2005-2007 & $\%$ \\
\hline Control (without film) & 2005 & 2006 & 2007 & & 100 \\
\hline Transparent original & 6655 & 9811 & 10042 & 9503 & 72.8 \\
Transparent recycled & 5649 & 6776 & 7878 & 6923 & 71.4 \\
Mean & 5882 & 6862 & 7846 & 6786 & 72.2 \\
\hline White original & 4702 & 4277 & 7862 & 6854 & 48.3 \\
White recycled & 4324 & 4567 & 5119 & 4670 & 49.1 \\
Mean & 4513 & 4422 & 4952 & 4629 & 48.7 \\
\hline Black original & 1562 & 1638 & 2591 & 1930 & 20.3 \\
Black recycled & 1817 & 2295 & 3331 & 2481 & 26.1 \\
Mean & 1689 & 1966 & 2961 & 2205 & 23.2 \\
\hline
\end{tabular}

The studies demonstrated that the colour of film had an effect on both: the length of stalks and the yield (Table 3). In 2005, the longest stalks were obtained from cultivation under black film $(27.3 \mathrm{~cm})$, whereas stalks obtained from under other materials were $2 \mathrm{~cm}$ shorter. In the following year of the experiment plants were generally smaller but stalks from cultivation under black and white film as well as the control were significantly longer than stalks of plants grown under transparent film. In the third year of the experiment the longest stalks were obtained from plants grown under transparent film $(27.2$ $\mathrm{cm}$ ) whereas in case of other covers the results were similar to the control. In the third year of trial stalks of plants grown under black film were $1 \mathrm{~cm}$ longer than stalks of plants grown under different covers. No differences were observed between the length of stalks grown under original or recycled films.

In 2005 the highest yield of stalks was obtained from the control treatment $\left(5.17 \mathrm{~kg} \cdot \mathrm{m}^{-2}\right)$ and from plots covered with transparent film $\left(4.79 \mathrm{~kg} \cdot \mathrm{m}^{-2}\right)$. In the following year, the stalk yield was significantly lower than in the first year of the experiment. In comparison with the control, the highest yield was obtained from plots covered with black $\left(3.53 \mathrm{~kg} \cdot \mathrm{m}^{-2}\right)$ and white film $\left(3.33 \mathrm{~kg} \cdot \mathrm{m}^{-2}\right)$. However, in the third year of the experiment, the highest stalk yield was noted for plants grown under transparent film $\left(4.20 \mathrm{~kg} \cdot \mathrm{m}^{-2}\right)$ and the yield from under control film was at the similar level. The lowest yield was obtained from plants grown under white film $\left(2.88 \mathrm{~kg} \cdot \mathrm{m}^{-2}\right)$. Mean values of the yield from three years of the experiment indicate that better results were obtained from plants with best light conditions (control treatment and transparent film). As compared with other films of lower solar radiation permeability, the results were however minor and never exceeded several percent.

The most evident negative effect of film colours on all studied parameters was demonstrated for black film used as tunnel structure cover. Results obtained in each year of the experiment showed that celery stalks grown under black film contained the least sugars and dry matter on harvest day (Table 4). 


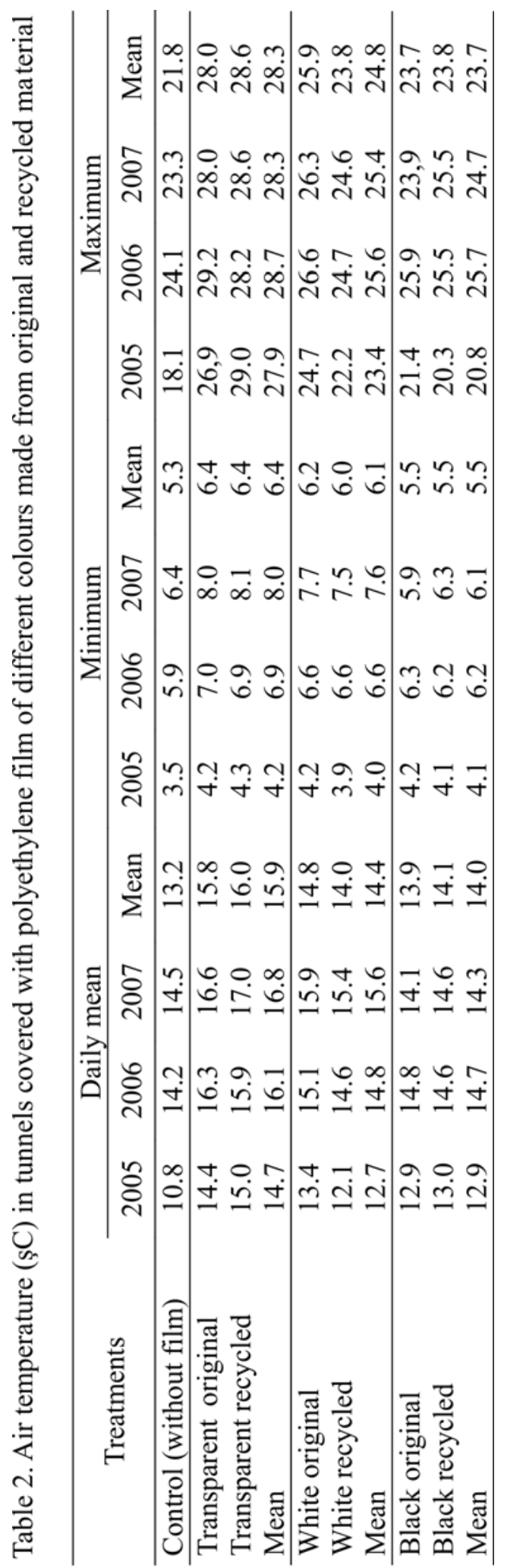




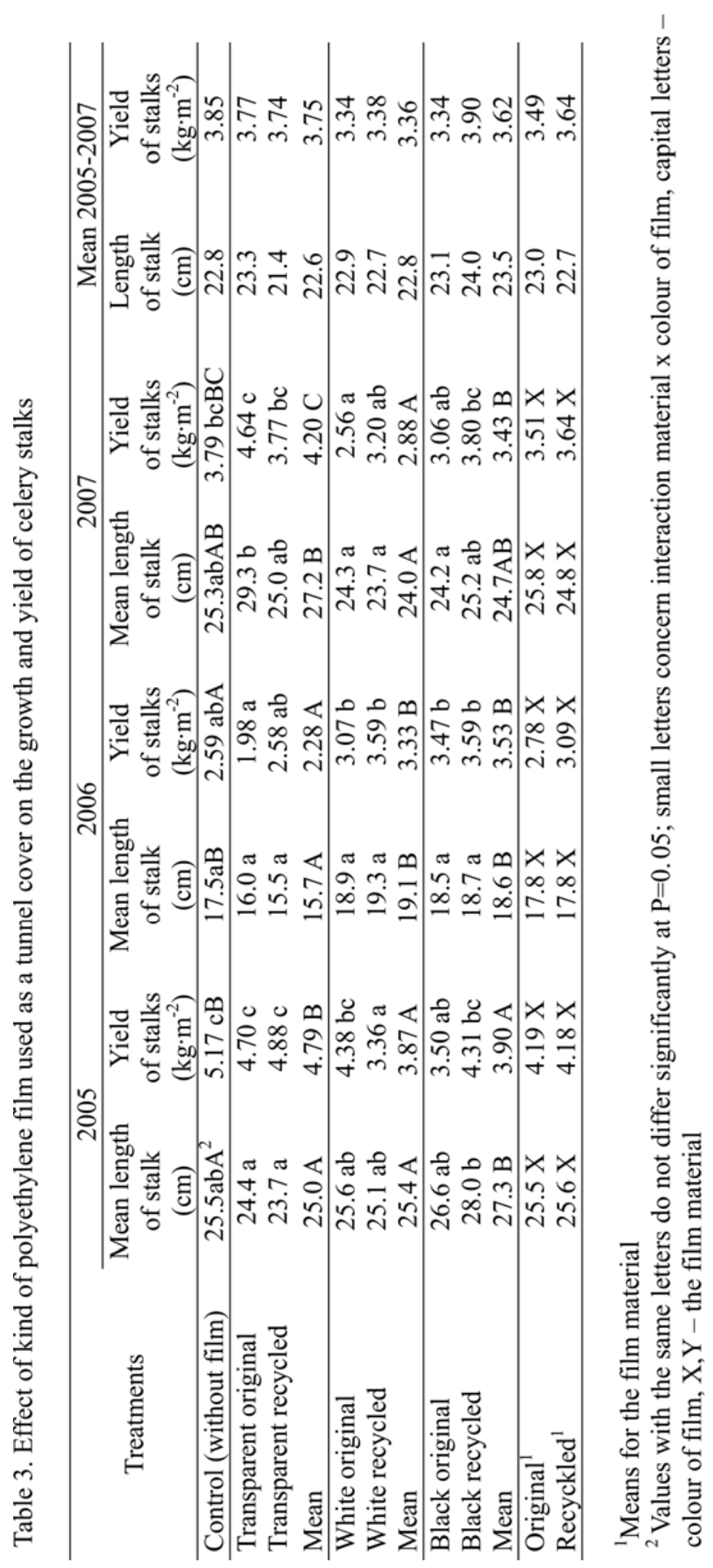




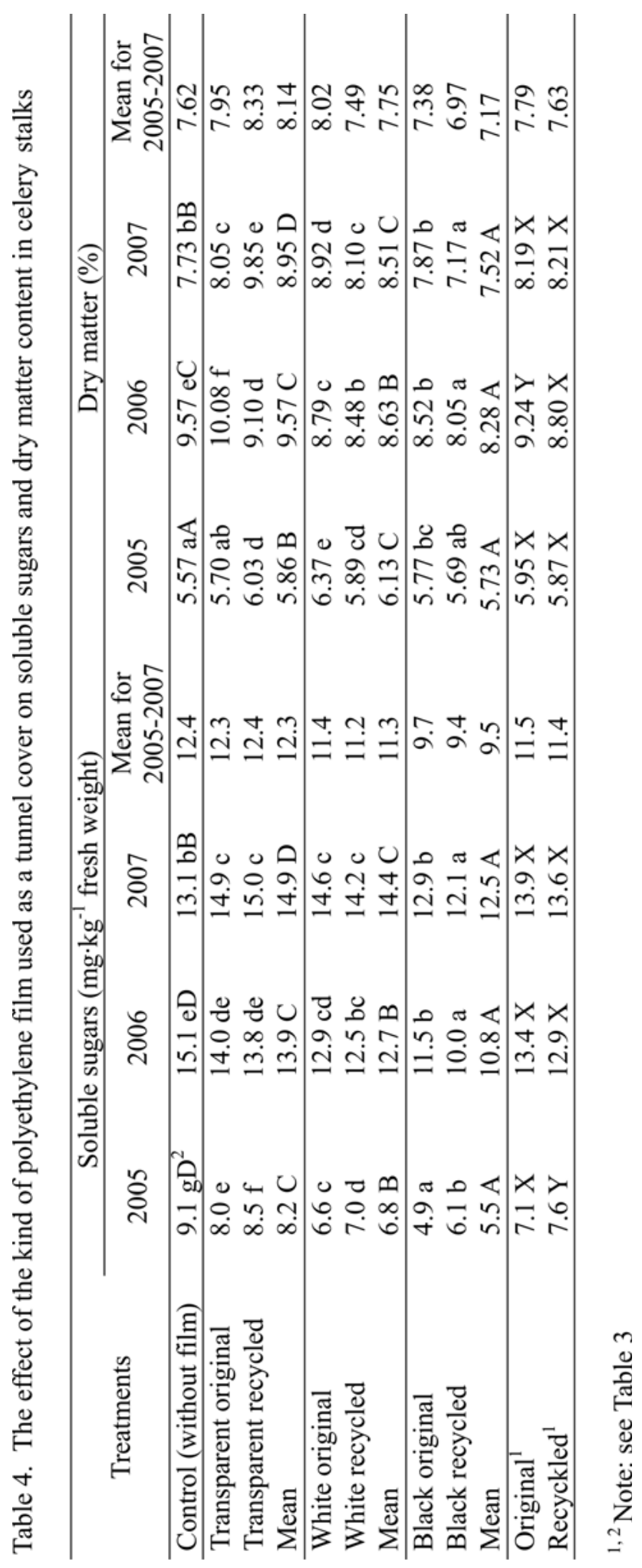


In years 2006-2007 that effect was even more significant in case of black recycled film. Plants grown in the initial vegetation period under tunnels covered with transparent (original and recycled) film had the highest content of soluble sugars. The lowest level of this compound was noted in case of plant covered with white film. Only in 2005 significant differences in soluble sugars content were found depending on the material of which transparent and white films were made, indicating higher values in plants grown under films made from recycled materials. In comparison with uncovered plants, in 2007 there was a significant increase of sugars content in stalks of celery cultivated in tunnels covered with transparent and white films. Such dependences in dry matter content were demonstrated not only in the last, but also in the first year of the experiment. However, the dry matter content in stalks of plants harvested from these plots differed depending on the year of the experiment. The highest content of dry matter was noted in stalks from plants cultivated until the end of May under transparent film of original material in 2006.

\section{DISCUSSION}

Minor differences in the length of celery stalks cultivated under different films indicate that plant growth was even, regardless of different light conditions in the initial vegetation period in the field. Similar results were obtained in experiment where the effect of identical films on the yield of lettuce was studied (Siwek et al. 2007). In previous studies it was also confirmed that growing cucumbers in low tunnels shaded with different materials, negatively effected elongation growth of stalks and decreased the yield. This may indicate that celery plants are more tolerant to light deficiency than cucumber (Siwek \& Ciura 1999). Significant growth limitation and lower yield were also obtained in case of sweet pepper as a result of covering low tunnels with polypropylene nonwoven fabric in different colours and with strong plant-shading properties (Siwek \& Libik 1999). The experiment proved that in case of strong light absorption by shades the amount of light reaching plants had greater effect than the light's spectral composition. The results of this study indicate a great tolerance of celery plants to solar radiation deficiency which may be important finding for horticultural practice.

The obtained results indicate that films used as a cover for low tunnels can significantly modify the level of soluble sugars and dry matter content in stalks. In this case plant cultivation in tunnels covered with transparent films was the most favourable due to the fact that transparent film (regardless of the origin of the material) transmits the most light. Plants cultivated in more favourable light conditions (under control treatment and under transparent film) during the whole period under cover generally accumulated more sugars in stalk yield than plants from under different materials. In celery leaves saccharose and mannitol are the biggest share in all soluble sugars. Both compounds are products of photosynthesis and are important in transport, with mannitol serving also as a storage compound (Davies et al. 1988). Due to the fact that limited access to 
light for assimilating parts of plants can lead to a decrease of assimilates also a decrease of foil permeability for PAR causes that the amount of sugars accumulated in stalks decreases. In the experiment concerning celery stalks shaded with various materials, soluble sugars and dry matter contents were the lowest in blades and stalks covered with black non-woven fabric for 14 days prior to harvest (Wojciechowska \& Siwek 2006).

However, it is interesting that in this experiment the yield from plants covered with black film (which average PAR transmission of 36.2\%), were satisfactory and in 2006 it was even higher than that obtained from plants grown in tunnels covered with transparent film. Presented results also indicate that celery plants often produce longer stalks in worse light conditions. This dependency may result from the fact that light, apart from the direct stimulating effect on photosynthesis, indirectly affects the morphological phenomena. The inverse effect of light and auxins on cell elongation process is well-known thus at conditions of light deficiency plants contain higher amount of auxins and their growth is more intensive than at normal light conditions (Kraepiel et al. 2001). Earlier studies also demonstrated that plants may form a bigger assimilation surface when the shading is stronger (Siwek \& Libik 1996). This may be connected with a lower water loss due to transpiration as a positive water balancing factor necessary for cell growth (Xu et al. 1994). Moreover, earlier studies showed that plants adapt to particular lighting conditions and very often maximal photosynthetic rate occurred in the irradiance to which the plants were adapted (Krug 1997). When black film shading period was over and plants were grown at normal light conditions for over a month, celery biomass was still increasing, however it was more hydrated and contained less soluble sugars.

\section{REFERENCES}

Davies J.M., Fellman J.K., Loescher W.H. 1988. Biosynthesis of sucrose and mannitol as a function of leaf age in celery (Apium graveolens L.). Plant Physiol. 86: 129-133.

Dyduch J. 1994. Celery cultivation for spring to autumn harvest. Acta Hort. 371: 275-282. Jenni S., Stewart K.A. 1992. Celery production as influenced by floating row covers. Proc. XII Congr. Int. de Plasticos en Agricultura, Granada, 35-41.

Jenni S., Gamache I., Cote J., Steward K. 2006. Plastic mulches and low tunnels to reduce bolting and increase marketable yield of early celery. J. Veg. Sci. 12(2): 57-73.

Kalisz A., Cebula S. 1995. Warunki wzrostu a wybijanie w pędy kwiatostanowe u kilku odmian kapusty pekińskiej w uprawie wiosennej. Mat. Sympozjum „Fizjologiczne aspekty produkcji ogrodniczej” AR Kraków: 77-81. [in Polish]

Kraepiel Y., Agnes Ch., Tiery L., Maldiney R., Miginiac E., Delarue M. 2001. The growth of tomato (Lycopersicon esculentum Mill.) hypocotyls in the light and in darkness differentially involves auxin. Plant Sci. 161: 1067-1074.

Krug H. 1997. Environmental influences on development, growth and yield. pp.: 101180. In: The physiology of vegetable crops, CAB International.

Libik A., Siwek P. 1994. Changes in soil temperature affected by the application of plastic covers in field production of lettuce and watermelon. Acta Hort. 371: 269-273.

Pressman E. 1997. Celery: The Physiology of Vegetable Crops. pp.: 387-407. CAB International. 
Siwek P., Ciura J. 1999. [Control of some stress microclimatic factors under plastic tunnels at cucumber cultivation.] Zesz. Probl. Post. Nauk Roln. 469(1): 127-135. [in Polish with English summary]

Siwek P., Libik A. 1996. Wpływ warunków mikroklimatu w tunelach foliowych z podwójnym przykryciem na wzrost i plonowanie papryki. Mat. Sympozjum "Nowe rośliny i technologie w ogrodnictwie" AR Poznań, 2: 63-68. [in Polish]

Siwek P., Wojciechowska R., Libik A., Kalisz A. 2007. [Effect of plant shading with plastic films of different colours on the content of assimilation pigments and nitrate metabolism in the leaf stalks of celery.] Roczn. AR Poznań, Ogrodnictwo 41: 609-614. [in Polish with English summary]

Siwek P. 2002. Modification of environmental conditions by mulching and direct plant covering in the culture of cucumber and stalk celery. Zesz. Nauk. AR Kraków 279: 52-64. [Polish with English summary]

Siwek P., Libik A. 1999. The impact of tunnel cover type on growth and yield of sweet pepper. Int. Agrophysics 13:119-124.

Wojciechowska R., Siwek P. 2006. The effect of shading on nitrate metabolism in stalks and blades of celery leaves (Apium graveolens L. var. dulce). Folia Hort. 18(2): 25-35.

Xu H.L., Gauthier L., Gosselin A. 1994. Photosynthetic responses of greenhouse tomato plants to high solution electrical conductivity and low soil water content. J. Hort. Sci. 69(5): 821-832.

Yemm E.W., Wills A.J. 1954. The estimation of carbohydrates in plant extracts by antrone. Biochem. J. 57: 508-514.

\section{PLON SELERÓW NACIOWYCH I ICH JAKOŚĆ W TUNELACH POKRYTYCH RÓŻNYMI RODZAJAMI FOLII POLIETYLENOWEJ}

Streszczenie
Wcześniejsze eksperymenty wykazały, że seler naciowy może być z powodzeniem uprawiany na zbiór wiosenny i jesienny pod osłonami wykonanymi z różnych folii, a czynnikiem w największym stopniu modyfikującym wielkość i jakość plonu były warunki świetlne. W trzyletnich doświadczeniach oceniano wpływ bezbarwnej, białej i czarnej folii pelietylenowej wykonanej z surowców oryginalnych i recyklingowych na tunelach niskich na wzrost, plon i wybrane parametry jakości ogonków liściowych selerów naciowych odmiany Tango. Pomiędzy poszczególnymi rodzajami folii nie stwierdzono różnic we wzroście elongacyjnym roślin. Jedynie pod folią czarna długość ogonków była o $1 \mathrm{~cm}$ większa niż w pozostałych obiektach. Plon ogonków liściowych był o kilka procent większy w przypadku stosowania folii bezbarwnej i w obiekcie kontrolnym. W lepszych warunkach świetlnych rośliny akumulowały więcej suchej masy i cukrów rozpuszczalnych. Stwierdzono, że większy wpływ na rośliny wykazała ilość promieniowania przepuszczanego przez folie niż jego skład spektralny. Nie obserwowano różnic pod wpływem folii oryginalnej i recyklingowej. 